\title{
Seasonal and circadian patterns of circulating prolactin during lactation and seasonal quiescence in the tammar, Macropus eugenii
}

\author{
L. A. Hinds and C. H. Tyndale-Biscoe \\ Division of Wildlife and Rangelands Research, CSIRO, P.O. Box 84, Lyneham, A.C.T. 2602, \\ Australia
}

\begin{abstract}
Summary. Prolactin was measured in peripheral plasma of female tammars once a week for 14 months and every 2 months it was measured in a subgroup of 7 tammars at hourly intervals for $28 \mathrm{~h}$ to determine short-term changes in concentration.

During the course of the study 6 females gave birth in January/February and reared their young to weaning in October-November, while another 4 gave birth 1.5-3.0 months later and weaned their young in November-December. Concentrations of prolactin were $<40 \mathrm{ng} / \mathrm{ml}$ in a non-lactating animal and for the first 140 days of lactation in the others. Between 140 and 180 days of lactation the concentrations of prolactin fluctuated between 10 and $>100 \mathrm{ng} / \mathrm{ml}$ and thereafter remained high until the young vacated the pouch for the last time at about 250 days. After pouch exit the concentrations declined to about $40 \mathrm{ng} / \mathrm{ml}$ even though lactation continued for a further 21-35 days. Although the short-term patterns of prolactin concentrations showed no consistent relationship between light-dark phases there was an increase in the magnitude and duration of peaks of plasma prolactin which correlated with the stage of lactation. Removal of pouch young aged between 203 and 242 days for $24 \mathrm{~h}$ resulted in a rapid decrease in plasma prolactin concentration which was reversed when the young was returned to the pouch, indicating that the high levels of prolactin in the second half of lactation may be maintained by the sucking stimulus of the pouch young. This period of lactation, therefore, may be equated with lactation in eutherians, but there appears to be no eutherian equivalent to early lactation in the tammar.
\end{abstract}

\section{Introduction}

In marsupials lactation rather than pregnancy is the period of major growth and development of the young and is of relatively longer duration than in equivalent-sized eutherians. Also, unlike eutherians there are marked changes in milk composition and production during lactation (Green, 1984) and a several-fold increase in the size of the active mammary gland (Smith, Brown \& Frith, 1969; Findlay, 1982; Stewart, 1984). During the first half of lactation the young is permanently attached to one teat and its increase in weight is slow. In the second half of lactation the weight gain accelerates and this period is thought to be equivalent to lactation in eutherians such as the horse and ruminants, which are born in an advanced state of development (Sharman, 1973).

For the tammar, Macropus eugenii, the major changeover in milk composition occurs between 170 and 220 days (Messer \& Green, 1979; Green, Newgrain \& Merchant, 1980; Green, 1984) and the 14-fold increase in mammary gland weight (Stewart, 1984), which is due to both hypertrophy and hyperplasia of the alveolar cells, occurs between 140 and 210 days (Findlay, 1982). Between 150 
and 200 days the young achieves homeostasis (Setchell, 1974), and vacates the pouch permanently at 250 days (Murphy \& Smith, 1970) although the young may suck and lactation continue for up to 350 days (W. E. Poole, personal communication).

While prolactin is essential for the maintenance of lactation in eutherian mammals (Ensor, 1978) much less is known of its role in lactation in marsupials, apart from Hearn's (1974) observation that the pituitary must be present for the maintenance of early and late lactation in the tammar. In non-lactating tammars seasonal changes in the concentration of plasma prolactin occur, with lowest levels during shortening daylength (February-June in Australia) and highest levels during lengthening days (September-November in Australia) (Tyndale-Biscoe \& Hinds, 1984). In Australia and New Zealand the majority of females give birth in January-February and lactate until late October or early November (Andrewartha \& Barker, 1969; Maynes, 1977), but little is known of the changes in concentrations of plasma prolactin associated with lactation, their relationship to the seasonal changes already described or whether there is a diurnal rhythm of prolactin release. Preliminary results from 2 females (Hinds \& Tyndale-Biscoe, 1982) indicated that the pattern of changes in concentrations of plasma prolactin during lactation contrasted markedly with the usual eutherian pattern in which circulating prolactin concentrations are highest in the early stages of lactation (Ensor, 1978; Cowie, Forsyth \& Hart, 1980).

The main aims of this study were to describe seasonal and short-term profiles in plasma prolactin throughout lactation in the tammar, and to examine the relationship between prolactin concentrations and the sucking stimulus of the young during late lactation.

\section{Materials and Methods}

\section{Animals}

The tammars used in these experiments came from the breeding colony established from Kangaroo Island stock and maintained at the CSIRO Division of Wildlife and Rangelands Research. Throughout the study the females, body weight $3.8-5.4 \mathrm{~kg}$, were held with adult males in outdoor pens; water and pelleted lucerne oats were available ad libitum.

\section{Experimental design}

Experiment 1. A group of female tammars (initially 14), taken from the breeding colony was used to determine seasonal changes (Exp. 1a) and short-term changes (Exp. 1b) in concentrations of plasma prolactin.

In Exp. 1a, for 14 months, from before birth in one breeding season until after birth in the following breeding season, all animals were examined once a week when a blood sample was taken for assay and the pouch was checked for the presence of the young. During the 2 breeding seasons the animals were examined daily for birth and oestrus and in the first year additional blood samples were taken at these times to detect changes in prolactin at parturition and oestrus. For the young the date of birth, the date of permanent pouch exit and the date when lactation ceased were recorded.

In Exp. 1b, on 6 occasions during the study (21-22 February; 20-21 April; 21-22 June; 23-24 August ; 25-26 October; 20-21 December) 5-7 animals were chosen at random from the group and blood samples were collected at hourly intervals from $08: 00 \mathrm{~h}$ on the first day to $11: 00 \mathrm{~h}$ on the next day. Throughout the sampling period the animals were held in jute sacks in a naturally lit room at ambient temperature. A light source with a red filter was used during the hours of darkness.

Experiment 2. Six lactating females were selected in October, and the ages of their pouch young were determined from head lengths compared with growth curves derived from tammars of known birth dates (W. E. Poole, unpublished data). At the start of the experiment the young ranged in age from 203 to 242 days and could be expected to remain in the pouch for a further 20 to 50 days. Each female's young was removed from the pouch, held in an incubator for $24 \mathrm{~h}$ then returned to the 
pouch. Blood samples were taken from each female at $09: 00 \mathrm{~h} 4$ days, 1 day and immediately before removing the pouch young. Further blood samples were collected $7 \mathrm{~h}$ and $24 \mathrm{~h}(09: 00 \mathrm{~h}$ on Day 1) after pouch young removal. The young was then replaced in its mother's pouch and further samples were collected $7 \mathrm{~h}$ later, and at 09:00 h on Days 2, 3 and 6.

\section{Collection of blood samples}

In Exps 1a and 2, blood samples $(2.5 \mathrm{ml})$ were taken between $08: 00$ and $10: 00 \mathrm{~h}$ from a lateral tail vein. In Exp. $1 \mathrm{~b}$ blood samples $(2.5 \mathrm{ml})$ were collected from jugular catheters which had been inserted 2 days earlier, as described by Khin Aye Than \& McDonald (1973). To prevent progressive anaemia developing the red blood cells from each hourly sample were resuspended in sterile sodium citrate and returned to the circulation after the next sample had been collected. After each shortterm sampling period the jugular catheters were removed and replaced when the animal was selected again. In the course of the 6 sampling periods each animal was used 1-4 times depending on the success of attempts to re-catheterize the jugular vein. Three animals died under anaesthetic (August, October and December) when the catheters were being re-inserted, and another died on 22 February after the first series of hourly samples.

The blood samples were placed on ice and within $1 \mathrm{~h}$ of collection were centrifuged at $1000 \mathrm{~g}$, then aliquants of plasma were frozen at $-20^{\circ} \mathrm{C}$ until assayed for prolactin. In Exp. 1 additional aliquants were taken for measurement of $\mathrm{LH}$ and FSH and the results will be reported elsewhere.

\section{Prolactin assays}

Plasma prolactin concentrations were determined by the heterologous radioimmunoassay of McNeilly \& Friesen (1978) validated for the tammar by Hinds \& Tyndale-Biscoe (1982) using antibody 33-9 and ovine prolactin NIH-P-S12 as standard. The limit of sensitivity was $3 \mathrm{ng} / \mathrm{ml}$, and intra- and inter-assay coefficients of variation were 8 and $12 \%$ respectively. The recovery of a range of concentrations of prolactin added to tammar plasma closely correlated with the actual amount added $(r=0.998, P<0.001)$ and was always within $12 \%$ of the expected value. All samples for an individual animal were analysed within one assay.

\section{Analysis of results}

To correlate the short-term changes in prolactin release with time of year and stage of lactation (Exp. 1b) areas under the curve were calculated using a digitiser programme for animals in which the 28-h profile was complete. The total area and the area above the median prolactin concentration for the $28 \mathrm{~h}$ period were determined. The area below the median prolactin concentration was calculated by subtraction.

In Exp. 2 analysis of variance gave highly significant $\mathrm{F}$ values. Individual $t$ tests were then used to compare values at the different sampling times.

\section{Results}

\section{Experiment 1}

Of the 14 animals used in the study 10 raised their young to independence, 3 died at various times before completion of lactation and 1 (No. 4107) displayed no reproductive activity throughout the year. Six of the $\mathbf{1 0}$ females that raised their young gave birth between 20 January and 4 February (mean \pm s.e.m. date of birth $=29$ January \pm 2.3 days, $N=6$ ) (Table 1 ) and their young first left the pouch between 5 October and 2 November (mean \pm s.e.m. date of pouch exit $=$ 25 October \pm 5 days, $N=6$ ) when they were 257 to 282 days old (mean \pm s.e.m. age of young at 
pouch exit $=269 \pm 4$ days, $N=6$ ). The other 4 females gave birth between 16 March and 4 May (mean \pm s.e.m. date of birth $=8$ April \pm 12 days, $N=4$ ) and their young vacated the pouch between 23 November and 28 December when they were 222-259 days old (mean \pm s.e.m. age $=$ $241 \pm 8$ days, $N=4$ ). Therefore, these young born 1.5-3.0 months later in the year vacated the pouch at a significantly earlier age (two-tailed $t$ test, $P<0.01$ ) than the 6 young born at the beginning of the breeding season.

In the following year all of the 9 surviving animals gave birth or showed oestrus between 19 January and 13 March. For 5 of these the date of birth or oestrus occurred within 1-4 days of the same date as in the previous season (Table 1).

Table 1. Breeding data of female tammars used in Exp. 1 to show the influence of time of birth on age of young at pouch exit

\begin{tabular}{|c|c|c|c|c|}
\hline $\begin{array}{c}\text { Animal } \\
\text { No. }\end{array}$ & $\begin{array}{c}\text { Date of } \\
\text { birth }\end{array}$ & $\begin{array}{l}\text { Date of } \\
\text { permanent } \\
\text { pouch exit }\end{array}$ & $\begin{array}{l}\text { Age of young } \\
\text { at permanent } \\
\text { pouch exit } \\
\text { (days) }\end{array}$ & $\begin{array}{c}\text { Date of birth } \\
\text { or oestrus in } \\
\text { subsequent } \\
\text { season }\end{array}$ \\
\hline 4485 & 20 Jan. & 5 Oct. & 258 & 19 Jan. \\
\hline 4411 & 24 Jan. & 2 Nov. & 282 & $20 \mathrm{Jan}$. \\
\hline 4210 & $30 \mathrm{Jan}$. & 25 Oct. & 268 & $30 \mathrm{Jan}$. \\
\hline 4573 & 31 Jan. & 2 Nov. & 275 & 29 Jan. \\
\hline 3970 & I Feb. & 2 Nov. & 275 & 31 Jan. \\
\hline 4638 & 4 Feb. & 19 Oct. & 257 & - \\
\hline Mean & 29 Jan. & 25 Oct. & 269 & $26 \mathrm{Jan}$. \\
\hline \pm s.e.m. & $2 \cdot 3$ days & 5 days & 4 days & $2 \cdot 6$ days \\
\hline 4698 & 16 Mar. & 30 Nov. & 259 & 2 Feb. \\
\hline 86938 & 23 Mar. & 23 Nov. & 245 & - \\
\hline 4178 & $20 \mathrm{Apr}$ & 28 Nov. & 222 & 6-13 Mar. \\
\hline 4506 & 4 May & 28 Dec. & 238 & 31 Jan. \\
\hline 4107 & - & - & - & 6-13 Mar. \\
\hline $\begin{array}{c}\text { Mean } \\
\pm \text { s.e.m. }\end{array}$ & $\begin{array}{r}8 \text { Apr. } \\
12 \text { days }\end{array}$ & $\begin{array}{l}4 \text { Dec. } \\
8 \text { days }\end{array}$ & $\begin{array}{c}241 \\
8 \text { days* }\end{array}$ & \\
\hline
\end{tabular}

* Young born later in the breeding season were significantly younger at pouch exit than those born in early February (two-tailed $t$ test, $P<0.01$ ).

Experiment la : seasonal changes in plasma prolactin concentrations. Individual profiles of plasma prolactin concentrations for the 6 females whose young were born at the end of January are presented in Text-fig. 1 and the mean profile in Text-fig. 2(a). Before birth, plasma prolactin levels were generally low except for a brief pulse at parturition, as previously described (Tyndale-Biscoe, Hinds, Horn \& Jenkin, 1983). With a few exceptions the concentrations remained at $<20 \mathrm{ng} / \mathrm{ml}$ for the first 140 days of lactation, i.e. from February to mid-June. From this time until 180 to 200 days (August) irregular fluctuations of between 40 and $100 \mathrm{ng} / \mathrm{ml}$ occurred, and thereafter concentrations were consistently higher than $60 \mathrm{ng} / \mathrm{ml}$, and generally greater than $100 \mathrm{ng} / \mathrm{ml}$ (the limit of the assay) for the next 50 to 80 days. Shortly before, or when the young permanently vacated the pouch at the end of October (Table 1), the concentrations of prolactin declined rapidly (Textfigs $1 \& 2 \mathrm{a}$ ). However, in these animals the young continued to suck as white milk could still be expressed from the sucked gland for a further $21-35$ days.

In the second group that retained their young to weaning similar changes in plasma prolactin concentrations occurred but at a correspondingly later time in the year, with the major rise in September and October (Text-fig. 2b) and the decline in November or December coincident with permanent pouch exit. In these animals the period of elevated prolactin concentration was maintained for only 40-50 days (Text-fig. $2 \mathrm{~b}$ ), possibly due to the earlier time of pouch exit by the young. 


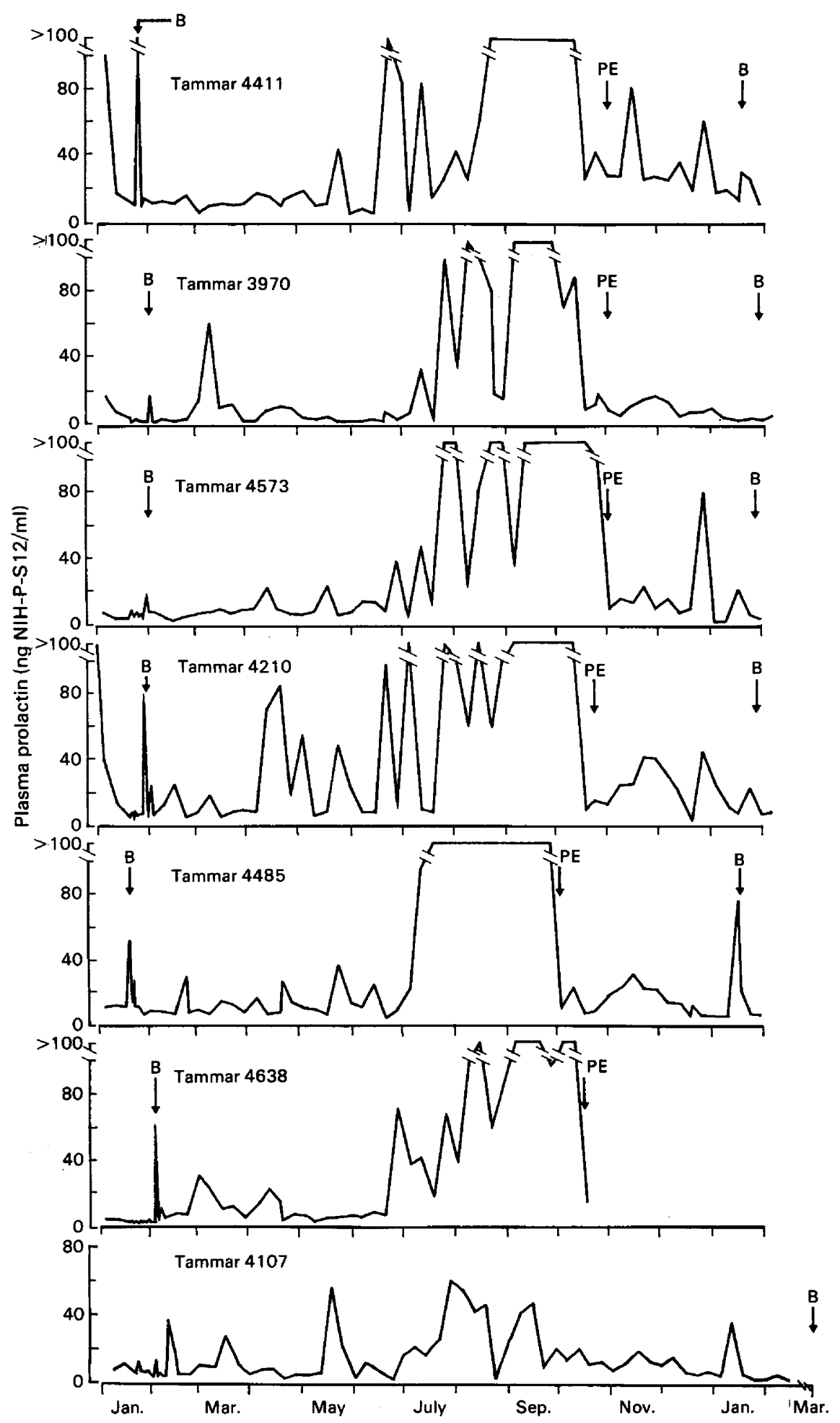

Text-fig. 1. Plasma prolactin concentrations in 6 tammars throughout lactation and in one female (No. 4107) that did not lactate. Samples were collected from before birth (B) in one season until after birth in the following season. The time of permanent pouch exit (PE) is indicated for each young animal. 


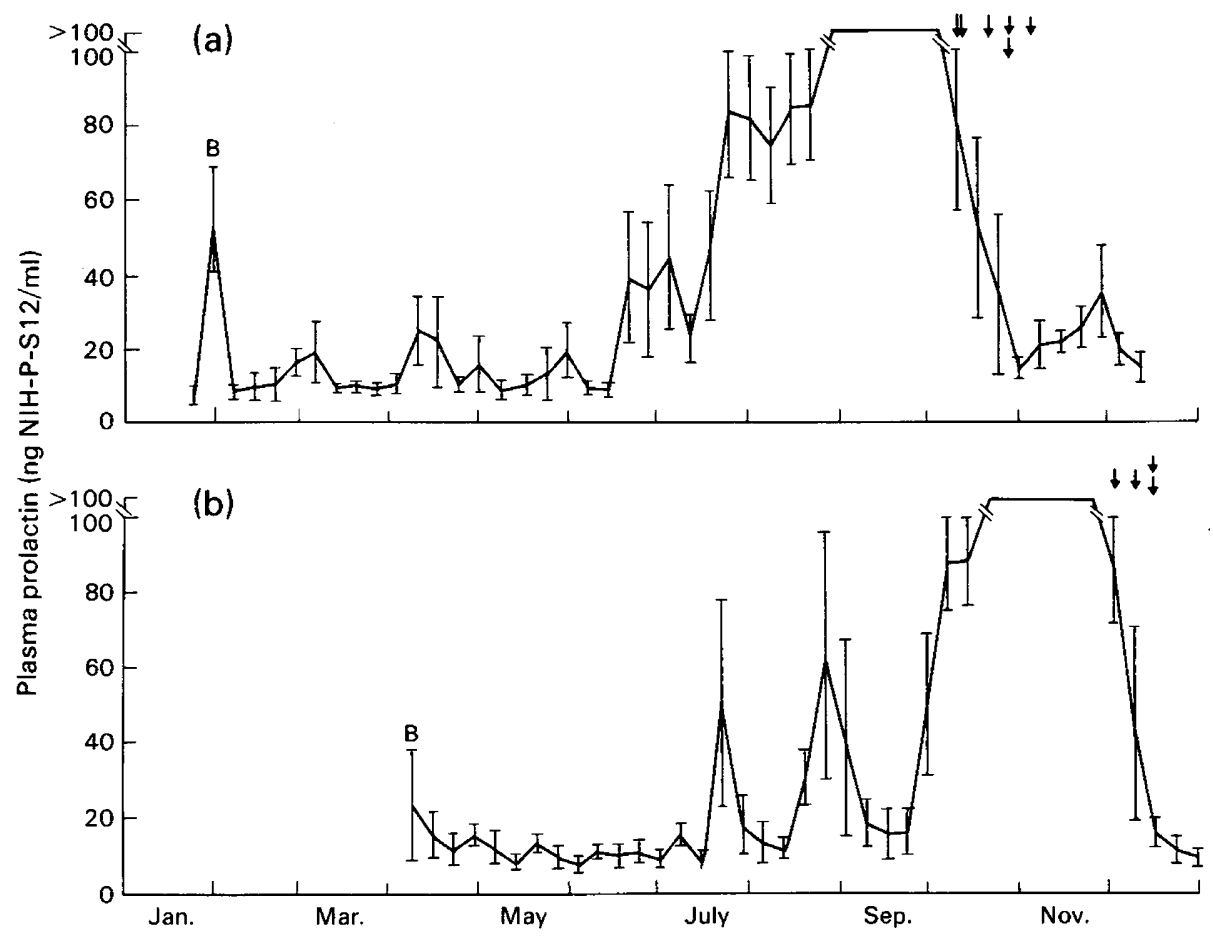

Text-fig. 2. Mean \pm s.e.m. plasma prolactin levels throughout lactation in tammars whose young were born (a) at the beginning of the breeding season $(\mathrm{N}=6)$ or $(\mathrm{b}) 1.5-3.0$ months later $(N=4)$. Profiles for these 4 animals have been synchronized to 8 April, the mean date of birth (B). Arrows indicate the time of permanent pouch exit.

By contrast plasma prolactin concentrations in the one non-lactating female, No. 4107 (Textfig, 1), did not display the marked changes seen in all 10 lactating females.

Experiment $1 b$ : short-term changes in plasma prolactin concentrations. The hourly changes in plasma prolactin during $28 \mathrm{~h}$ at 6 times of the year are shown for individual animals in Text-fig. 3 . Mean results could not be presented as the animals were at different stages of lactation during any one sampling period. There was no evidence of a consistent relationship between light-dark phases and prolactin concentration in any animal. There was no change in the one non-lactating female throughout the year but the short-term pattern of plasma prolactin concentration in the lactating females did change considerably with respect to the time of year and the stage of lactation. In early lactation in February (Text-fig. 3) prolactin secretion over the 28-h period remained low and stable while in April, June and August 1-3 peaks of prolactin release occurred during the sampling period in all animals. Between April and August as lactation proceeded there was an increase in the magnitude ( $<40$ to $>80 \mathrm{ng} / \mathrm{ml}$ ) and duration (1-2 to 3-5 h) of these peaks (Text-fig. 3). However, after pouch exit (October to December) prolactin concentrations remained low and stable during the entire 28 -h period. Analyses of the short-term profiles showed significant correlations with both the time of lactation (17-203 days) and the time of year (February to August). For the total amount of prolactin versus time of lactation, $r=0.652(P<0.005, n=17)$, and versus time of year, $r=$ $0.669(P<0.005, n=20)$. For peak prolactin episodes (area above median prolactin concentration) versus time of lactation, $r=0.837(P<0.0005, n=17)$, and versus time of year, $r=0.802(P<$ $0.005, n=17$ ). Beyond 200 days of lactation and after August the correlations were not significant, since by the next sampling interval in October prolactin concentrations had declined in most of the females coincident with the exit of the young from the pouch (Text-fig. 2). 


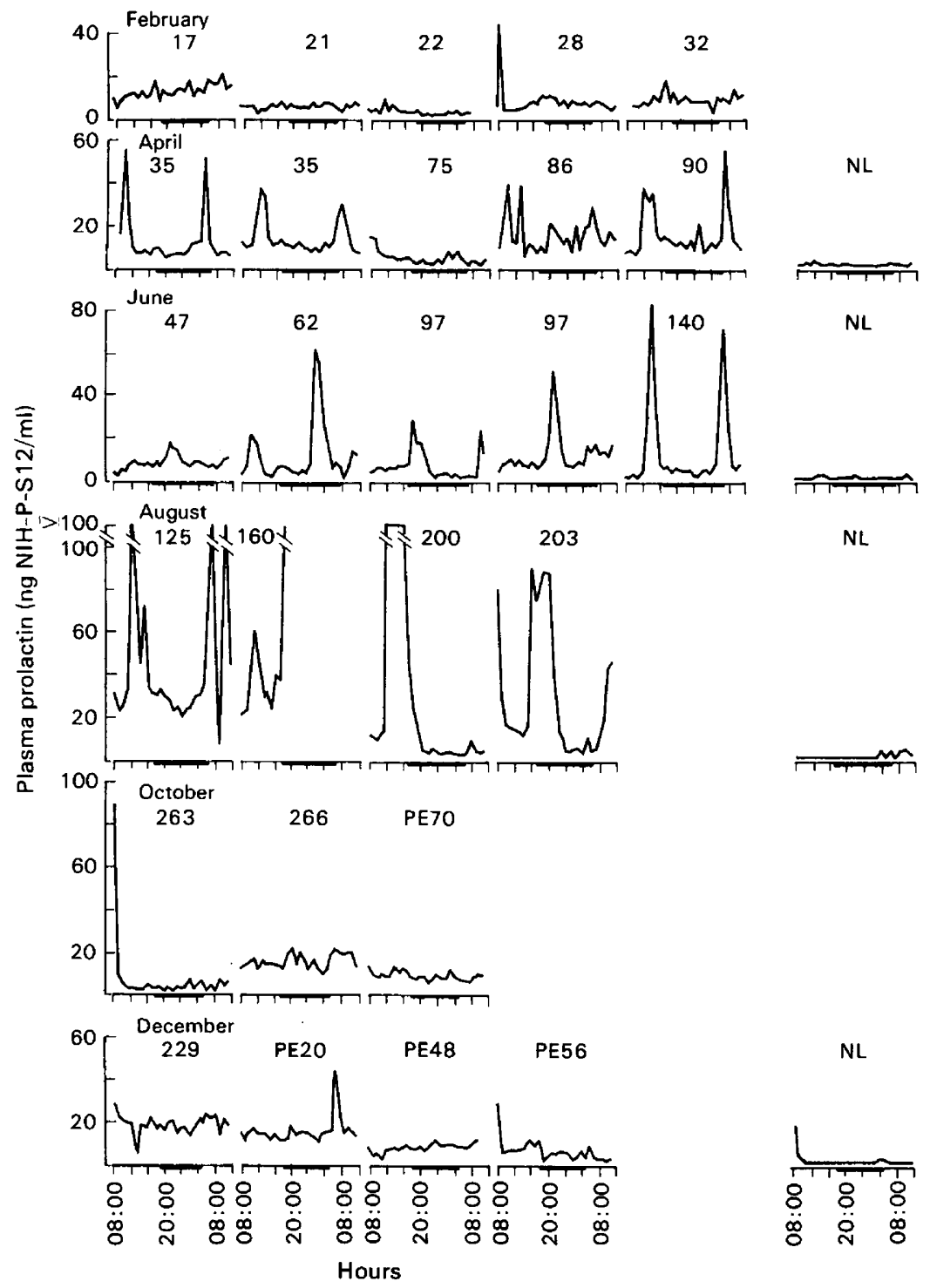

Text-fig. 3. Plasma prolactin concentrations in tammars bled every hour for $28 \mathrm{~h}$ every 2 months throughout the year. Profiles for individual animals are shown since the length of lactation varied for animals at each sampling time. Numbers above each profile indicate the duration of lactation (days) or the time since permanent pouch exit (PE days). NL, nonlactating. Horizontal bars on the axes indicate hours of darkness.

Experiment 2: effect of removal and replacement of the pouch young on plasma prolactin concentrations during late lactation

Peripheral prolactin concentrations for the 4 days before removal of the pouch young were $>80$ $\mathrm{ng} / \mathrm{ml}$, which is within the range seen at this stage of lactation in Exp. 1a (Text-fig. 4). By $7 \mathrm{~h}$ after removal of the pouch young the concentrations had decreased to $40 \mathrm{ng} / \mathrm{ml}$ (two-tailed $t$ test, $P<$ 0.01 ) and remained at this concentration until the young were replaced. At $7 \mathrm{~h}$ after return of the young prolactin concentrations were again high $(t$ test, $P<0.05)$ and remained elevated throughout the next 5 days. 


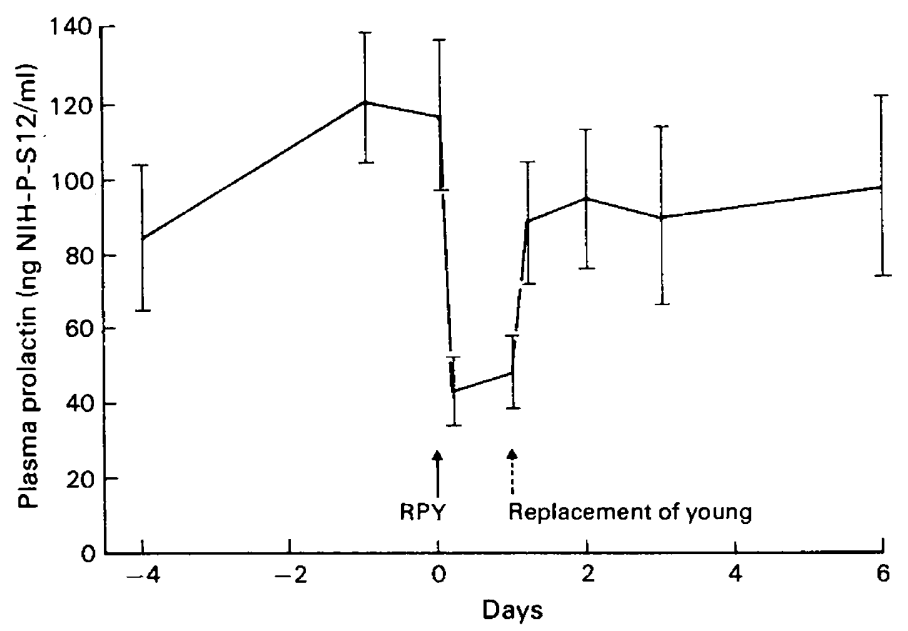

Text-fig. 4. Mean \pm s.e.m. plasma prolactin concentrations during late lactation (203-242 days) in tammars $(\mathrm{N}=6$ ) before and after removal of pouch young (RPY), and after replacement of the young in the pouch.

\section{Discussion}

While a seasonal change in plasma prolactin occurs in non-lactating tammars (Tyndale-Biscoe \& Hinds, 1984) the results of this study indicate that the presence of the young in the pouch is the overwhelming influence on prolactin secretion in the tammar. Clearly the overall pattern of secretion differs from that described for eutherian mammals (Cowie et al., 1980), although similarities in response to sucking are observed in the second half of lactation. There is no parallel in eutherians for the pattern in early lactation in the tammar. The low levels of plasma prolactin before 140 days of lactation, which are no greater than in non-lactating females at this time of year (Hinds \& Tyndale-Biscoe, 1982; Tyndale-Biscoe \& Hinds, 1984; this study), indicate that the sucking stimulus plays no part in establishing the concentrations of prolactin at this time. This is in marked contrast to the response elicited by the sucking stimulus of eutherian neonates (rat: Amenomori, Chen \& Meites, 1970; cow: Karg \& Schams, 1974; goat: Buttle, Forsyth \& Knaggs, 1972; Hart, 1974; sheep: Lamming, Moseley \& McNeilly, 1974; marmoset: McNeilly, Abbott, Lunn, Chambers \& Hearn, 1981; pig: Bevers, Willemse \& Kruip, 1978; red deer: Loudon, McNeilly \& Milne, 1983). Nevertheless, it is very likely that prolactin or other anterior pituitary hormones are essential for galactopoiesis at this stage in the tammar since lactation ceases within a few days of full or anterior hypophysectomy and the young die 7-21 days after operation (Hearn, 1974; L.A. Hinds, C. A. Horn \& C. H. Tyndale-Biscoe, unpublished observations). It has been suggested by Stewart (1984) that the low levels of plasma prolactin during early lactation may be effective because of the differential development of specific receptors for prolactin on the plasma membranes of the secretory cells in the sucked gland. In the sucked gland the receptor concentration per cell greatly exceeds the concentration in adjacent unsucked glands and reaches a maximum by about 84 days after the start of lactation, although the total number of receptors in the gland continues to increase as the gland undergoes hyperplasia. Between 120 and 240 days there is a 14-fold increase in the size of the gland, with the greatest increase occurring between 140 and 200 days (Stewart, 1984) and this increase coincides with the progressive rise in plasma prolactin to maximum concentrations by about Day 200. It also coincides with the change in milk composition 
from high to low carbohydrate content (Messer \& Green, 1979), from low to high fat content (Green et al., 1980; Green, Griffiths \& Leckie, 1983) and from low to high electrolyte concentration (Green \& Newgrain, 1979). These changes occur after the young has begun to relinquish the teat at about 100 days (Murphy \& Smith, 1970), and may be associated with a change in sucking pattern from continuous to intermittent; before 100 days of lactation the weight of the young increases slowly and daily milk intake ranges between 1 and $4 \mathrm{ml} /$ day (Green, 1984). Beyond this time there is a marked increase in milk consumption and body weight, so that by 200 days the average intake of milk is about $50 \mathrm{ml} /$ day (Green, 1984). These changes in milk intake and composition probably reflect the increasing energetic requirements of the young which, between 100 and 200 days, achieves homeostasis; its thermoregulatory and metabolic functions develop (Setchell, 1974; Paton \& Janssens, 1981) and the thyroid, adrenal and pituitary glands begin to secrete their respective hormones (Setchell, 1974; Call, Catling \& Janssens, 1980; Wilkes, 1984). Furthermore, it is during this period that the incremental growth rate of the young accelerates (W. E. Poole, personal communication), closely paralleling the accelerated growth of the active mammary gland (Stewart, 1984) and the rising level of plasma prolactin.

While there was no evidence of a diurnal rhythm in the release of prolactin, as has been described for several eutherians (rat: Dunn, Arimura \& Scheving, 1972; man: Sassin, Frantz, Weitzman \& Kapen, 1972; monkey: Quadri \& Spies, 1976; sheep: Barrell \& Lapwood, 1978; cat: Banks \& Stabenfeldt, 1983), there were marked changes which correlated with the stage of lactation of the female. As lactation proceeded, although the number of peaks of prolactin remained the same (1-3 every $28 \mathrm{~h}$ ), the magnitude and duration of these peaks increased until August, after which time the young vacated the pouch. Whether these peaks are a direct response to the sucking of the young is not known but together with the marked response to removal and replacement of the pouch young, at least in the second half of lactation, this can be inferred. Since the changes in plasma prolactin in response to removal and replacement of young at this time are similar to those seen in lactating sows whose piglets were removed and replaced (Bevers et al., 1978), the second half of lactation in the tammar may be equated to the early stages of lactation in eutherians. Furthermore, the decline in prolactin concentrations at the time of pouch exit probably reflects a decrease in frequency of sucking as the young is weaned from a milk to a vegetarian diet, and so parallels the decline in prolactin concentrations observed at weaning in eutherians; in women, for example, who are exclusively breast feeding and then introduce their young to supplementary food there is a marked decline in sucking frequency and a corresponding decrease in plasma prolactin concentrations (Howie \& McNeilly, 1982).

During the course of lactation in the tammars the temporal sequence of the changes in prolactin concentration was maintained independently of the month when the young were born, indicating that the pattern is inherent to the stage of lactation. Nevertheless, the period of highest prolactin concentration in the second half of lactation was shortened in the females that carried later born young. Although these young were born about 2.5 months later than most they vacated the pouch only 1 month after the young born earlier. This difference in time of pouch exit may reflect differences in the quality of the diet available to both mother and young between October and December.

While it appears from our results that the rise in prolactin in the second half of lactation is induced by the sucking of the developing young, at this stage we cannot say whether these changes in prolactin concentrations are directly responsible for the changes in growth of the mammary gland and the altered composition of the milk it secretes. Nevertheless, the results help to explain the old paradox of how a kangaroo can simultaneously secrete two kinds of milk to nourish a young in the pouch and an older young out of the pouch (Lemon \& Bailey, 1966; Griffiths, McIntosh \& Leckie, 1972). By the time the older young vacates the pouch and is replaced by a newborn young the prolactin concentration has declined to levels similar to those at the onset of lactation. Thus lactation can be established in the newly sucked gland while permitting maintenance of milk production in the functioning gland. 
We thank Carol Horn, Roy Coles and Ray Leckie for assistance with the collection of blood samples, and Dr Alan McNeilly, MRC Reproductive Biology Unit, Edinburgh, U.K., for the gift of prolactin antiserum. This work formed part of the Ph.D. thesis of L.A.H. and she thanks Dr Peter A. Janssens, Zoology Department, Australian National University, Canberra for constructive comments throughout the study.

\section{References}

Amenomori, Y., Chen, C.L. \& Meites, J. (1970) Serum prolactin levels in rats during different reproductive states. Endocrinology 86, 506-510.

Andrewartha, H.G. \& Barker, S. (1969) Introduction to a study of the ecology of the Kangaroo Island Wallaby, Protemnodon eugenii (Desmarest) within Flinders Chase, Kangaroo Island, South Australia. Trans. Roy'. Soc. S. Aust. 93, 127-132.

Banks, D.R. \& Stabenfeldt, G.H. (1983) Prolactin in the cat. II. Diurnal patterns and photoperiod effects. Biol. Reprod. 28, 933-939.

Barrell, G.K. \& Lapwood, K.R. (1978) Effects of pinealectomy of rams on secretory profiles of luteinizing hormone, testosterone, prolactin and cortisol. Neuroendocrinology 27, 216-227.

Bevers, M.M., Willemse, A.H. \& Kruip, Th. A.M. (1978) Plasma prolactin levels in the sow during lactation and the post-weaning period as measured by radioimmunoassay. Biol. Reprod. 19, 628-634.

Buttle, H.L., Forsyth, I.A. \& Knaggs, G.S. (1972) Plasma prolactin measured by radioimmunoassay and bioassay in pregnant and lactating goats and the occurrence of a placental lactogen. $J$. Endocr. 53, 483-491.

Call, R.N., Catling, P.C. \& Janssens, P.A. (1980) Development of the adrenal gland in the tammar wallaby, Macropus eugenii (Desmarest) (Marsupialia : Macropodidae). Aust. J. Zool. 28, 249-259.

Cowie, A.T., Forsyth, I.A. \& Hart, I.C. (1980) Hormonal Control of Lactation. Springer-Verlag, Berlin.

Dunn, J.D., Arimura, A. \& Scheving, L.E. (1972) Effect of stress on circadian periodicity in serum $\mathbf{L H}$ and prolactin concentration. Endocrinology 90, 29-33.

Ensor, D.M. (1978) Comparative Endocrinology of Prolactin. Chapman and Hall, London.

Findlay, L. (1982) The mammary glands of the tammar wallaby (Macropus eugenii) during pregnancy and lactation. J. Reprod. Fert. 65, 59-66.

Green, B. (1984) Composition of milk and energetics of growth in marsupials. Symp. zool. Soc. Lond. 51, 369 387.

Green, B. \& Newgrain K. (1979) Estimation of the milk intake of sucklings by means of ${ }^{22} \mathrm{Na}$. J. Mammal. 60, 556-559.

Green, B., Newgrain, K. \& Merchant, J. (1980) Changes in milk composition during lactation in the tammar wallaby (Macropus eugenii). Aust. J. biol. Sci. 33, 35 . 42.

Green, B., Griffiths, M. \& Leckie, R.M.C. (1983) Qualitative and quantitative changes in milk fat during lactation in the tammar wallaby (Macropus eugenii). Aust. J. biol. Sci. 36, 455-461.

Griffiths, M., McIntosh, D.L. \& Leckie, R.M.C. (1972) The mammary glands of the red kangaroo with observations on the fatty acid components of the milk triglycerides. J. Zool., Lond. 166, 265-275.

Hart, I.C. (1974) The relationship between lactation and the release of prolactin and growth hormone in the goat. J. Reprod. Fert. 39, 485-499.

Hearn, J.P. (1974) The pituitary gland and implantation in the tammar wallaby, Macropus eugenii. J. Reprod. Fert. 39, 235-241.

Hinds, L.A. \& Tyndale-Biscoe, C.H. (1982) Prolactin in the marsupial Macropus eugenii, during the estrous cycle, pregnancy and lactation. Biol. Reprod. 26, 391398.

Howie, P.W. \& McNeilly, A.S. (1982) Effect of breastfeeding patterns on human birth intervals. J. Reprod. Fert. 65, 545-557.

Karg, H. \& Schams, D. (1974) Prolactin release in cattle. J. Reprod. Fert. 39, 463-472.

Khin Aye Than \& McDonald, I.R. (1973) Adrenocortical function in the Australian brush-tailed possum, Trichosurus vulpecula (Kerr). J. Endocr. 58, 97-109.

Lamming, G.E., Moseley, S.R. \& McNeilly, J. (1974) Prolactin release in the sheep. J. Reprod. Fert. $\mathbf{4 0}$, 151-168.

Lemon, M. \& Bailey, L.F. (1966) A specific protein difference in the milk from two mammary glands of a red kangaroo. Aust. J. exp. Biol. Med. Sci. 44, 705708.

Loudon, A.S.I., McNeilly, A.S. \& Milne, A.J. (1983). Nutrition and lactational control of fertility in red deer. Nature, Lond. 302, 145-147.

Maynes, G.M. (1977) Breeding and age structure of the population of Macropus parma on Kawau Island, New Zealand. Aust. J. Ecol. 2, 207-214.

McNeilly, A.S. \& Friesen, H.G. (1978) Heterologous radioimmunoassay for rabbit prolactin. Endocrino$\log y$ 102, 1539-1547.

McNeilly, A.S., Abbott, D.H., Lunn, S.F., Chambers, P.C. \& Hearn, J.P. (1981) Plasma prolactin concentrations during the ovarian cycle and lactation and their relationship to return of fertility post partum in the common marmoset (Callithrix jacchus). J. Reprod. Fert. 62, 353-360.

Messer, M. \& Green, B. (1979) Milk carbohydrates of marsupials. II. Quantitative and qualitative changes in milk carbohydrates during lactation in the tammar wallaby (Macropus eugenii). Aust. J. biol. Sci. 32, 519531.

Murphy, C.R. \& Smith, J.R. (1970) Age determination of pouch young and juvenile Kangaroo Island wallabies. Trans. R. Soc. S. Aust. 94, 15-20.

Paton, B.C. \& Janssens, P.A. (1981) Metabolic changes associated with the switch from a milk to a vegetable diet in the tammar wallaby Macropus eugenii (Desmarest). Comp. Biochem. Physiol. 70B, 105-113. 
Quadri, S.K. \& Spies, H.G. (1976) Cyclic and diumal patterns of serum prolactin in the rhesus monkey. Biol. Reprod. 14, 495-501.

Sassin, J.F., Frantz, A.G., Weitzman, E.D. \& Kapen, S. (1972) Human prolactin: 24-hour pattern with increased release during sleep. Science, N.Y. 177, 12051207.

Setchell, P.J. (1974) The development of thermoregulation and thyroid function in the marsupial Macropus eugenii (Desmarest). Comp. Biochem. Physiol. 47A, 1115-1121.

Sharman, G.B. (1973) Adaptations of marsupial pouch young for extra-uterine existence. In The Mammalian Fetus in Vitro, pp. 67-90. Ed. C. R. Austin. Chapman and Hall, London.

Smith, M.J., Brown, B.K. \& Frith, H.J. (1969) Breeding of the brush-tailed possum, Trichosurus vulpecula (Kerr), in New South Wales. CSIRO WildI. Res. 14, 181-193.
Stewart, F. (1984) Mammogenesis and changing prolactin receptor concentrations in the mammary glands of the tammar wallaby (Macropus eugenii). J. Reprod. Fert. 71, 141-148.

Tyndale-Biscoe, C.H. \& Hinds, L.A. (1984) Seasonal patterns of circulating progesterone and prolactin and the response to bromocriptine in the female tammar Macropus eugenii. Gen. comp. Endocr. 53, 5868.

Tyndale-Biscoe, C.H., Hinds, L.A., Horn, C.A. \& Jenkin, G. (1983) Hormonal changes at oestrus, parturition and post-partum oestrus in the tammar wallaby (Macropus eugenii). J. Endocr. 96, 155-161.

Wilkes, G.E. (1984) The development of structure and function of the kidney in the tammar wallaby, Macropus eugenii. Ph.D. thesis, Australian National University, Canberra.

Received 7 September 1984 